University of Nebraska - Lincoln

DigitalCommons@University of Nebraska - Lincoln

Faculty Papers and Publications in Animal

Science

Animal Science Department

November 1979

\title{
REPRODUCTIVE CHARACTERISTICS OF BOARS DURING AND AFTER EXPOSURE TO INCREASED AMBIENT TEMPERATURE
}

R. P. Wettemann

Oklahoma Agricultural Experiment Station, Stillwater

M. E. Wells

Oklahoma Agricultural Experiment Station, Stillwater

R. K. Johnson

University of Nebraska-Lincoln, rjohnson5@unl.edu

Follow this and additional works at: https://digitalcommons.unl.edu/animalscifacpub

Part of the Animal Sciences Commons

Wettemann, R. P.; Wells, M. E.; and Johnson, R. K., "REPRODUCTIVE CHARACTERISTICS OF BOARS DURING AND AFTER EXPOSURE TO INCREASED AMBIENT TEMPERATURE " (1979). Faculty Papers and Publications in Animal Science. 80.

https://digitalcommons.unl.edu/animalscifacpub/80

This Article is brought to you for free and open access by the Animal Science Department at DigitalCommons@University of Nebraska - Lincoln. It has been accepted for inclusion in Faculty Papers and Publications in Animal Science by an authorized administrator of DigitalCommons@University of Nebraska - Lincoln. 


\title{
REPRODUCTIVE CHARACTERISTICS OF BOARS DURING AND AFTER EXPOSURE TO INCREASED AMBIENT TEMPERATURE 1,2
}

\author{
R. P. Wettemann ${ }^{3}$, M. E. Wells ${ }^{3}$ and R. K. Johnson ${ }^{4}$ \\ Oklaboma Agricultural Experiment Station, Stillwater 74074 \\ and USDA, SEA, El Reno 73036
}

\section{Summary}

Reproductive performance of 1211 -monthold Yorkshire boars was determined during and after exposure to control or increased ambient temperatures. After 3 weeks adjustment at $23 \mathrm{C}$ in temperature controlled chambers, six boars were heat stressed by exposure to $34.5 \pm 1.0 \mathrm{C}$ for $8 \mathrm{hr}$ and $31.0 \pm 1.0 \mathrm{C}$ for $16 \mathrm{hr}$ during each 24-hr period and six control boars were maintained at $23.0 \pm 1.0 \mathrm{C}$ for 11 weeks. All boars were subsequently exposed to $23 \mathrm{C}$ for 6 weeks. Semen was collected twice weekly before, during and after heat stress and boars were naturally mated with gilts during weeks 7 to 11 of treatment. Daily rectal temperatures and respiratory rates were increased during heat stress, but the ability to ejaculate and semen volume were not altered. Percentage motile sperm was decreased during heat stress $(\mathrm{P}<.005)$ and did not return to normal values until 5 weeks after the end of exposure to increased ambient temperatures. Daily sperm output from heat stressed boars was decreased $(\mathrm{P}<.025)$ during daily ejaculation on days 33 to 38 of treatment and averaged $54 \%$ of the total sperm ejaculated by control boars. At 30 days after natural breeding only $59 \%(\mathrm{P}<.05)$ of the gilts bred by heat stressed boars were pregnant compared to $82 \%$ for gilts mated to control boars.

\footnotetext{
1 Journal Article No. 3550 of the Agr. Exp. Sta., Oklahoma State Univ., Stillwater. This research was conducted in cooperation with USDA, SEA Southern Region.

${ }^{2}$ The authors express their appreciation to $\mathrm{R}$. Vencl for assistance throughout this study.

${ }^{3}$ Animal Science Dept., Oklahoma State Univ., Stillwater 74074 .

${ }^{4}$ Present address: Dept. of Animal Science, The Univ. of Nebraska, Lincoln 68503.
}

(Key Words: Boar, Fertility, Heat Stress, Semen Quality.)

\section{Introduction}

Reproductive performance of boars is reduced during the hot summer months (Thibault et al., 1966). Exposure of boars to increased ambient temperatures results in a reduction in semen quality (McNitt and First, 1970; Wettemann et al., 1976). This decrease in semen quality during heat stress of boars is associated with reduced pregnancy rates and increased embryonic mortality (Christenson et al., 1972; Wettemann et al., 1976). Exposure of boars to increased ambient temperature for 3 days, caused a reduction in semen quality that persisted for 6 to 8 weeks after treatment (McNitt and First, 1970; Christenson et al., 1972). Similarly, fertility was reduced in rams after short term whole body exposure to increased ambient temperatures (Howarth, 1969). Duarte Irala (1973) observed that motility of bovine sperm returned to normal about 8 to 10 weeks after exposure to increased ambient temperatures.

This study was designed to evaluate sperm output and fertility of boars during long term exposure to increased ambient temperature and to investigate semen quality during the first 6 weeks following heat stress.

\section{Materials and Methods}

Twelve 11-month-old Yorkshire boars of proven fertility were randomly allotted to an experimental or control temperature chamber $(3.7 \times 3.7 \mathrm{~m})$. Each chamber was divided into equal compartments so that three boars could be maintained individually. One replicate with six boars was initiated in October and the second began in April. Boars were trained to mount a dummy and semen was collected by 1501 
the hand technique. After all boars had been collected weekly for at least 3 weeks and had been exposed to ambient temperatures less than $23 \mathrm{C}$ for 6 weeks, a 3 week adjustment period at $23.0 \pm 1.0 \mathrm{C}$ was started. Following the adjustment period, the temperature in one chamber was increased to $34.5 \pm 1.0 \mathrm{C}$ from 0900 to $1500 \mathrm{hr}$ and reduced to $31.0 \pm 1.0 \mathrm{C}$ for the remaining $16 \mathrm{hr}$ during each 24-hr period for 11 weeks. Boars in this chamber were termed, heat stressed boars. They were subsequently exposed to $23 \pm 1 \mathrm{C}$ for 6 weeks. Control boars were maintained at $23 \pm 1 \mathrm{C}$ throughout the experiment. Humidity was not controlled but ranged from 25 to $40 \%$ and from 40 to $60 \%$ in the experimental and control chambers, respectively. Boars were exposed to $12 \mathrm{hr}$ of light daily starting at 0700 hours. Water was available at all times but feed intake was controlled so that boars gained about .20 $\mathrm{kg}$ per day. Boars were fed once daily at 0900 hours.

Rectal temperatures and respiratory rates were recorded daily at 1300 hr during treatment. Boars were ejaculated between 0900 and 1100 twice weekly (once daily on Tuesday and Friday) during the adjustment period, during the first 6 weeks of treatment, and for 6 weeks after heat stress. An exception to the above ejaculation regimen was during days 33 through 38 of treatment, when boars were collected daily to evaluate the effect of frequent ejaculation on sperm output. Semen volume, sperm output, motility and morphology were evaluated weekly as previously described (Wettemann et al., 1976).

Between weeks 6 and 11 of the treatment period, each boar was naturally mated to six or seven 8- to 10-month-old crossbred gilts of Duroc, Hampshire and Yorkshire breeding. Gilts were bred on the first and second days of estrus between 0900 and $1100 \mathrm{hr}$ and were slaughtered at day $30 \pm 3$ of pregnancy for determination of the numbers of corpora lutea and normal embryos. Embryo length was used to determine normalcy of embryos (Johnson and Omtvedt, 1973).

Rectal temperatures, respiratory rates and semen data were analyzed within periods (before, during and after treatment) by splitplot analysis of variance (Gill and Hafs, 1971) with two between-block treatments (replicate and ambient temperature) and one within block treatment (day of treatment). Embryo survival data were analyzed by analysis of variance and fertility data were analyzed by the MannWhitney Test (Conover, 1971).

\section{Results and Discussion}

Average rectal temperatures at $1300 \mathrm{hr}$ during the 11 weeks of treatment were increased $(\mathrm{P}<.05)$ to $38.8 \pm .1 \mathrm{C}$ for boars exposed to increased ambient temperature compared to $38.4 \pm .1 \mathrm{C}$ for control boars. Respiratory rates determined at the same time were increased $(\mathrm{P}<.05)$ about threefold in heat stressed compared to control boars $(92.8 \pm 9.9$ vs $30.8 \pm 4.1$, breaths per min, respectively). These increases in rectal temperatures and respiratory rates during heat stress are similar to those previously reported (Wettemann et al., 1976). Boars did not lose the ability to ejaculate, as reflected by ejacula collected from all boars throughout the experiment. The volume of semen produced by control and heat stressed boars was similar $(\mathrm{P}>.10)$ before, during and after treatment (figure 1). This concurs with previous studies which indicate that semen volume, which is produced by the accessory reproductive glands, is not altered by acute (McNitt and First, 1970) or chronic (Wettemann et al., 1976) heat stress, although heat stress of boars can provoke a marked alteration in testicular androgen biosynthesis (Wettemann and Desjardins, 1979).

Percentage of motile sperm was similar $(P>.10)$ in control and heat stressed boars before trearment and averaged $79 \pm 3 \%$ for all boars (figure 2). However, the percentage of motile sperm from boars during heat stress was reduced $(\mathrm{P}<.005)$ when compared to control

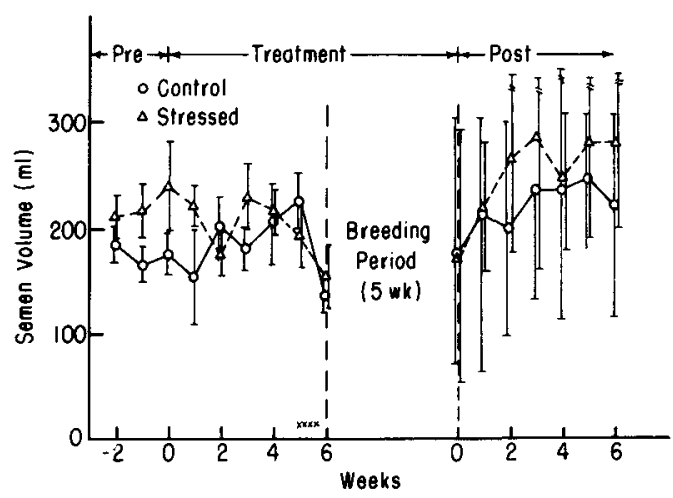

Figure 1. Semen volume from control and heat stressed boars before, during and after exposure to elevated ambient temperature. $X \times X \times$, Daily ejaculation period. 


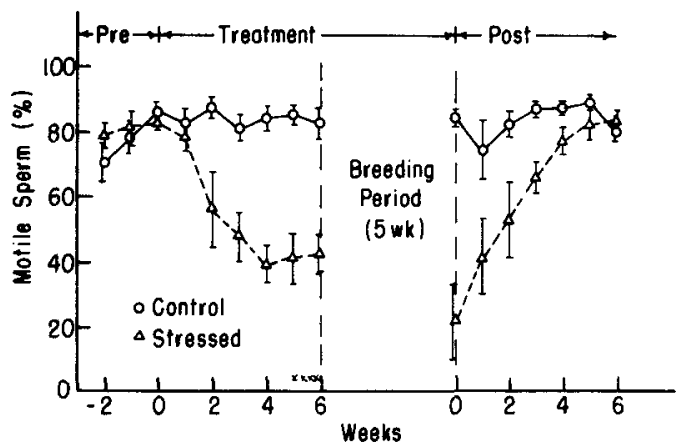

Figure 2. Percentage motile sperm from control and heat stressed boars before, during and after exposure to elevated ambient temperature. $x \times x \times$, Daily ejaculation period.

boars. By 2 weeks after the start of heat stress only $56 \pm 12 \%$ of the sperm were motile and during 4 through 6 weeks of treatment, sperm motility decreased to $40 \pm 9 \%$. When treatment was terminated at the end of the 5 week breeding period, $84 \pm 2 \%$ of sperm from control boars were motile compared to $21 \pm 12 \%$ for sperm from heat stressed boars. Percentage of motile sperm in stressed boars gradually increased during the 6-week period at $23 \mathrm{C}$. However, it was not until 5 weeks after the end of exposure to elevated ambient temperatures that percentage motile sperm was similar for control and stressed boars ( $89 \pm 2$ vs $82 \pm 5 \%$, respectively, $\mathrm{P}>.10$ ). The lag in time ( 2 weeks) from initiation of heat stress until motility of ejaculated sperm starts to deteriorate has been previously observed in boars (McNitt and First, 1970; Wettemann et al., 1976) and bulls (Zaremba, 1975) and indicates that sperm in the epididymis are more resistant to heat stress than sperm in the testis. Alternatively, epididymal function may not be altered until after several days of heat stress. The interval from the cessation of heat stress until ejaculation of sperm with normal motility appears shorter in boars compared to bulls exposed to whole body heat (Duarte Irala, 1973) or with elevated scrotal temperatures (Gerona and Sikes, 1970). This species difference could be due to differences in the duration of the cycle of the seminiferous epithelium. When boars are injected with thymidine-[methyl- ${ }^{3} \mathrm{H}$ ], 25 days are required before the ${ }^{3} \mathrm{H}$ label is present in sperm leaving the testes (Swierstra, 1968). This time interval is 41 days for bulls (Orgebin, 1961). The duration of sperm transit through the

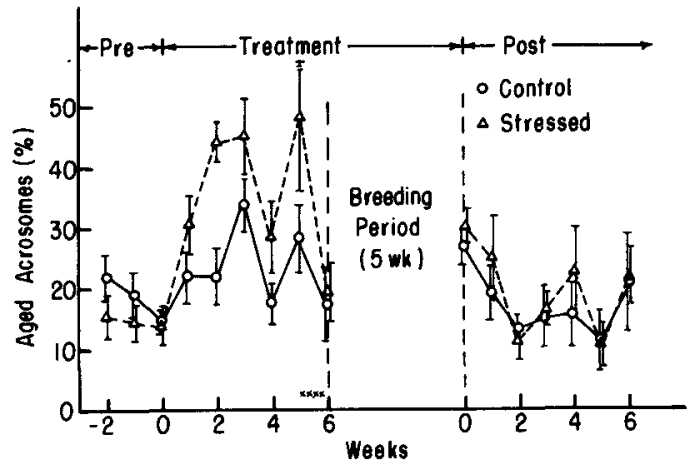

Figure 3. Percentage of sperm with aged acrosomes from control and heat stressed boars before, during and after exposure to elevated ambient temperature. $x \times x \times$, Daily ejaculation period.

epididymis is similar for boars and bulls and ranges from 9 to 12 days for boars (Swierstra, 1968 ) and 8 to 11 days in bulls (Orgebin, 1961). Other possible reasons for the different recovery times for boars and bulls from the cessation of heat stress until ejaculation of sperm with normal motility could be the stage of spermatogenesis affected or the severity and duration of increased testicular temperature.

Control and heat stressed boars had similar acrosome characteristics prior to treatment (figure 3). During 2 to 5 weeks of treatment, heat stressed boars had an increased $(P<.05)$ percentage of sperm with aged acrosomes compared to control boars ( $37 \pm 6$ vs $24 \pm 6 \%$, respectively). During the post-treatment period, percentage of sperm with aged acrosomes was similar for heat stressed and control boars. The

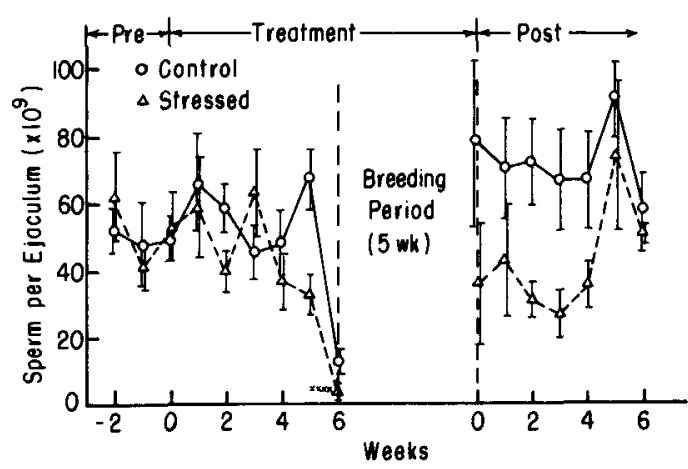

Figure 4. Total sperm per ejaculum from control and heat stressed boars before, during and after exposure to elevated ambient temperature. $X \times X X$, Daily ejaculation period. 
TABLE 1. TOTAL SPERM $\left(\times 10^{\circ}\right)$ PER EJACULUM FROM CONTROL AND HEAT STRESSED BOARS DURING DAILY EJACULATION

\begin{tabular}{llr}
\hline & & \multicolumn{1}{c}{ Treatment $^{\mathrm{D}} \begin{array}{c}\mathrm{b} \\
\text { treatment }\end{array}$} \\
\cline { 2 - 3 } & Control & Heat stressed \\
\hline 33 & $48.1 \pm 10.9 \mathrm{c}$ & $26.8 \pm 4.2$ \\
34 & $33.3 \pm 8.7$ & $11.2 \pm 2.6$ \\
35 & $19.7 \pm 4.7$ & $15.8 \pm 6.7$ \\
36 & $13.1 \pm 4.4$ & $8.9 \pm 3.4$ \\
37 & $16.5 \pm 4.6$ & $13.2 \pm 5.9$ \\
38 & $18.0 \pm 6.4$ & $3.5 \pm 1.7$ \\
\hline
\end{tabular}

\footnotetext{
${ }^{a}$ Significant day effect $(P<.01)$.

${ }^{\mathrm{b}}$ Significant treatment effect $(\mathrm{P}<.025)$.

$\mathrm{c}_{\text {Mean }} \pm \mathrm{SE}$.
}

reason for the similarity in the percentage of sperm with aged acrosomes from control and stressed boars immediately after the cessation of treatment is not apparent.

Sperm output was similar for control and heat stressed boars before and during treatment (figure 4). After the 11 weeks of heat stress, sperm output was decreased in heat stressed boars compared to control boars. There was a significant $(\mathrm{P}<.001)$ week by treatment interaction. Sperm output was reduced between 2 and 4 weeks after the termination of exposure to elevated ambient temperature. In a previous study (Wettemann et al., 1976), a reduction in sperm output was observed during heat stress with an approximately $50 \%$ reduction in gonadal and extragonadal sperm in heat stressed boars compared to control boars after 90 days of treatment. Since there is much variation in sperm output, the boars were ejaculated daily during days 33 to 38 of the treatment in the present study to determine if the effects of heat stress on sperm output are more pronounced with daily ejaculation. As would be expected, daily sperm output decreased in both control and heat stressed boars with time $(\mathrm{P}<.01$; table 1). Sperm output of boars during days 33 to 38 of heat stress was reduced $(\mathrm{P}<.025)$ averaging about $54 \%$ that of control boars. McNitt and First (1970) and Christenson et al. (1972) also reported decreased sperm output from boars after 3 days of heat stress.

Fertility of heat stressed boars was reduced (table 2). When six control boars were mated, $82 \%$ of the gilts were pregnant at 30 days after breeding, but only $59 \%(\mathrm{P}<.05)$ of the gilts bred by heat stressed boars conceived. Fertility of the individual boars subjected to heat stress was variable. Individual conception rates for the six stressed boars were $20,40,62,62,82$ and $88 \%$, whereas, between 75 and $100 \%$ of the gilts bred to each of the control boars were pregnant. This type of individual boar variation in response to heat stress exists for some semen

TABLE 2. FERTILITY OF GILTS MATED WITH CONTROL OR HEAT STRESSED BOARS

\begin{tabular}{|c|c|c|c|c|c|}
\hline \multirow[b]{2}{*}{ Treatment } & \multirow[b]{2}{*}{$\begin{array}{l}\text { No. of } \\
\text { boars }\end{array}$} & \multirow[b]{2}{*}{$\begin{array}{l}\text { No. of } \\
\text { gilts bred }\end{array}$} & \multicolumn{3}{|c|}{$\begin{array}{c}\text { Gilts pregnant at } 30 \pm 3 \text { days } \\
\text { after breeding }\end{array}$} \\
\hline & & & No. & Percentab & $\begin{array}{l}\text { Embryo } \\
\text { survival }\end{array}$ \\
\hline Control & 6 & 37 & 30 & 82 & $82.0 \pm 2.0$ \\
\hline Heat stressed & 6 & 40 & 25 & 59 & $78.7 \pm 4.5$ \\
\hline
\end{tabular}

\footnotetext{
${ }^{a}$ Average of the percentage of gilts pregnant for each boar.

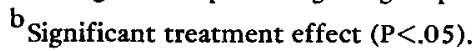


traits as well as fertility. However, since boars were not ejaculated for scmen quality determinations during the breeding season, the relationship between semen quality and fertility of individual boars could not be determined in this study.

In contrast to a previous experiment (Wettemann et al., 1976) embryo survival to $30 \pm 3$ days after breeding was not influenced by heat stress of the boars. Natural matings were utilized in the present study, whereas in the earlier study artificial inseminations were performed with 6 billion total sperm that were used fresh on the first day of estrus and stored until the second day of breeding. This observation suggests that sperm cell quality may not have an effect on litter size at 30 days after breeding when excess nonstored sperm are deposited by natural mating.

We conclude that whole body exposure of boars to increased ambient temperature ( 31 and $34.5 \mathrm{C}$ for 6 weeks) does not influence the ability to ejaculate or semen volume, but the percentage motile sperm is decreased and the number of sperm with aged acrosomes is increased. Percentage motile sperm from boars did not return to normal until 5 weeks after the end of heat stress. The reduction in semen quality during heat stress of boars is associated with decreased fertility after natural breeding.

\section{Literature Cited}

Christenson, R. K., H. S. Teague, $\Lambda$. P. Grifo, Jr. and W. L. Roller. 1972. The effect of high environmental temperature on the boar. Ohio Swine Research and Information Rep. Research Summary 61, Ohio Agricultural Research and Development Center, Wooster.

Conover, W. J. 1971. Practical nonparametric statistics. John Wiley and Sons, Inc., New York.

Duarte Irala, P. N. 1973. Auswirkungen experimenteller warmebelastung aut verschiedene korper- reaktionen und ejakulatbeschaffenheit bei fleckviehbullen vor deren cinsatz in heiben klimazonen. Thesis. Aus dem Institut fur Haustierbesamung und-andrologie. Hanover, Germany.

Gill, J. L. and H. D. Hafs. 1971. Analysis of repeated measurements of animals. J. Anim. Sci. 33:331.

Gerona, G. R. and J. D. Sikes. 1970. Liffects of elevated scrotum temperature on spermatogenesis and semen characteristics. J. Dairy Sci. 53:659 (Abstr.).

Howarth, B., Jr. 1969. Fertility in the ram following exposure to elevated ambient temperature and humidity. J. Reprod. Fertil. 19:179.

Johnson, K. K. and I. T. Omtvedt. 1973. Evaluation of purebreds and two-breed crosses in swine: Reproductive performance. J. Anim. Sci. 37: 1279.

McNitt, J. I. and N. L. First. 1970. Effects of 72-hour heat stress on semen quality in boars. Int. J. Biometeor. 14:373.

Orgebin, M. C. 1961. Etude du transit epididymaire des spermatozoides de taureau marques a l'aide du ${ }^{32}$ P. Annuls Biol. Anim. Biochim. Biophys. $1: 117$.

Swierstra, E. E. 1968. Cytology and duration of the cycle of the seminiferous epithelium of the boar; duration of spermatozoan transit through the epididymis. Anat. Rec. 161:171.

Thibault, C., M. Courot, L. Martinet, P. Mauleon, F. du Mesnil du Buisson, R. Ortavant, J. Pelletier and J. P. Signoret. 1966. Regulation of breeding season and estrous cycles by light and external stimuli in some mammals. J. Anim. Sci. $25: 119$. Suppl.

Wettemann, R. P., M. E. Wells, I. T. Omtvedt, C. E. Pope and E. J. Turman. 1976. Influence of elevated ambient temperature on reproductive performance of boars. J. Anim. Sci. 42:664.

Wettemann, R. P. and C. Desjardins. 1979. Testicular function in boars exposed to elevated ambient temperature. Biol. Reprod. 20:235.

Zaremba, W. 1975. Das verhalten von ejakulatmerkmalen nach unterschiedlich starken experimentenlen warmebelastungen bei jungbullen unter besondercr berucksichtigung der samenzellmorphologie und der glutamat-oxalacetattransaminase (GOT)-Aktivitat im seminalplasma. Thesis. Aus dem Institut fur Haustierbesamung und andrologie. Hanover, Germany. 